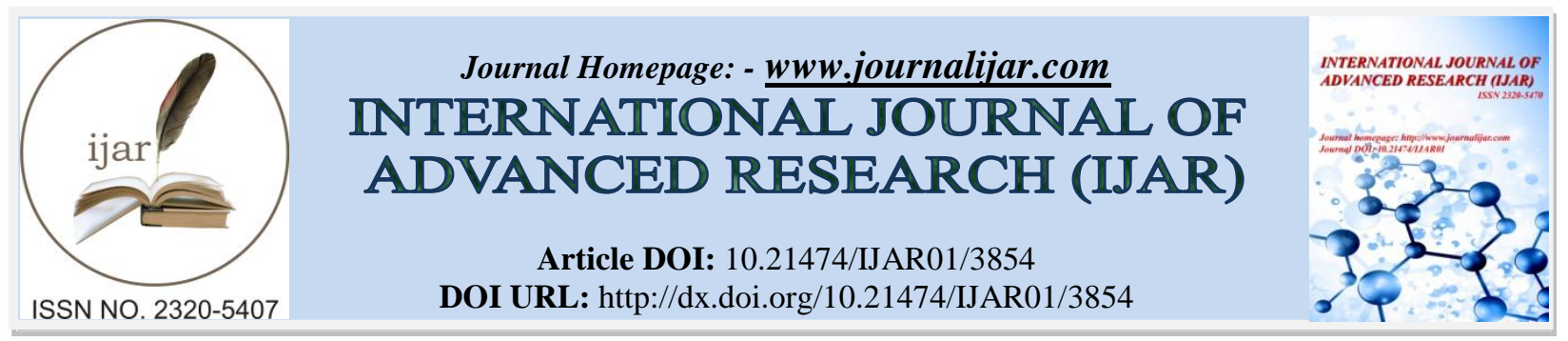

RESEARCH ARTICLE

\title{
ARDISIA NAYARII (PRIMULACEAE - MYRSINOIDEAE) - A NEW SPECIES FROM WESTERN GHATS, INDIA.
}

\author{
G. Rajkumar, A. Nazarudeen, M. Alister and A.G. Pandurangan \\ Jawaharlal Nehru Tropical Botanic Garden and Research Institute, Palode, Thiruvananthapuram, Kerala, India.
}

\section{Manuscript Info}

(..........................

Manuscript History

Received: 02 February 2017

Final Accepted: 03 March 2017

Published: April 2017

Key words:-

Ardisia nayarii, new species, Western

Ghats, Kerala, India.

\section{Abstract}

Ardisia nayarii is described and illustrated as a new species from Western Ghats, India. The species is distinguished from A. paniculata Roxb. by its distinctly petioled, decurrent glabrous leaves, rosy pink panicles, many ovules per flower and sub globose black berries.

Copy Right, IJAR, 2017,. All rights reserved.

\section{Introduction:-}

The genus Ardisia Swartz has about 500 species distributed all over the subtropical and tropical regions of the world including East and South East Asia, Africa, America and Australia. There are about 400 species in Asia alone (Mao $\& \mathrm{Hu}, 2013)$. The genus Ardisia is the largest in the sub family Myrsinoideae of the enlarged Primulaceae as per APG III classification (2009). Ardisia is classified into 14 sub genera based on characters such as habit, leaf morphology, structure, position of inflorescence and floral morphology (Mez, 1902). In India it has been represented by 25 species and one variety, 13 of which are endemic. In the Western Ghats, there are 12 species and one variety (Hooker, 1882; Nayar \& Giri, 1975; Nayar et al., 2014), inhabiting mainly in semi evergreen, evergreen and shola forests.

\section{Materials and Methods:-}

During floristic explorations in the Achankovil forests of Kollam district of Kerala, falling under the core area of Agasthyamala Biosphere Reserve of southern Western Ghats, the authors have collected an interesting specimen of Ardisia Swartz. On critical observation and comparison with available species deposited at Botanical Survey of India, Southern Regional Center (MH), Coimbatore, Calicut University Herbarium (CALI) and relevant literature (Hooker, 1882; Gamble, 1923; Nayar et al., 2014) it is revealed that the taxon is quite different from any of the hitherto described taxa of Ardisia, hence described and illustrated as new species. Specimens were collected and processed as per the procedures given by Jain and Rao (1977).

\section{Results and Discussion:-}

A critical study on the present species based on the characteristic features such as large leaves with gland dots, sub verticillate nature, inflorescence in special branches on indetermined lateral axis of the primary terminal, sub umbellate flowers, short filament and many ovules reveals that it belongs to the subgenus Pyrgus (Mez, 1902).

The species described here, closely resembles A. paniculata Roxb., a species that was collected and described by Roxburgh (1824) from Chittagong and Khasi hills of North East India by sharing certain characters such as 
conspicuously large leaves, long panicles and calyx lobes with ciliate margins. At the same time, it differs from the latter by its distinctly petioled glabrous leaves, rosy pink inflorescences, up to $2 \mathrm{~cm}$ long pedicels, black berries etc making it morphologically distinct from the former.

Table 1:- Comparison of characters between Ardisia paniculata and A. nayarii

\begin{tabular}{|l|l|l|}
\hline Characters & A. paniculata & A. nayarii \\
\hline Petiole & Sub sessile & Distinctly petioled to $1.5 \mathrm{~cm}$ \\
\hline Leaf size & $10-32 \times 3-6.5 \mathrm{~cm}$ & $15-35 \times 5-10 \mathrm{~cm}$ \\
\hline Leaf base & Rounded to auricled & Prominently decurrent \\
\hline Panicle shape & Oval & Pyramidal \\
\hline Pubescence & Rusty pubescent & Smooth glabrous \\
\hline Colour & Green & Rosy pink \\
\hline Secondary peduncles & $20-25$ nos. & $12-18$ nos. \\
\hline Tertiary branches & More common & Rarely observed \\
\hline Flowers & \pm 200 in dense umbels & $<100$ in lax umbels \\
\hline Pedicels & Up to $0.7 \mathrm{~cm}$ & Up to $2 \mathrm{~cm}$ \\
\hline Ovule & 1 & Many \\
\hline Berry & Red, globose, $0.5-0.7 \mathrm{~cm}$ across & $\begin{array}{l}\text { Black, sub globose, } 0.8-1 \mathrm{~cm} \\
\text { across }\end{array}$ \\
\hline
\end{tabular}

Ardisia nayarii G. Rajkumar, A. Nazarudeen, M. Alister et Pandurangan sp.nov. (Figs. 1 \& 2).

The new species, Ardisia nayarii is closely allied to A. paniculata Roxb. in having shrubby nature, coriaceous leaves and panicled inflorescence. It differs in having decurrent glabrous, distinctly petioled leaves, glabrous peduncles and pedicels, rosy pink panicles, many ovules and black subglobose berries.

Type: INDIA, Kerala, Kollam District, Achankovil, \pm 250 m, 20 February 2015 G. Rajkumar, A. Nazarudeen \& M. Alister, 84111(Holotype: TBGT; Isotype: MH).

Shrubs, 0.75-2.5 m high, stem terete, lateral branches horizontal or slightly drooping, bark smooth, grey-brown. Leaves sub-verticillate, crowded towards tip, oblanceolate, 15-35 $\times 5-10 \mathrm{~cm}$, coriaceous, often gland dotted, light brown on drying, entire, base decurrent, apex acute to acuminate, lateral veins 10-15 pairs, oblique, arching, mid rib prominent; petiole $0.5-1.5 \mathrm{~cm}$ long, glabrous, pinkish brown; bracts $1-1.4 \times 0.3-0.4 \mathrm{~cm}$, lanceolate, glabrous, revolute towards tip. Inflorescence panicled 12-24 cm long, pyramidal, terminal on lateral branches, lenticelled, glabrous, rosy pink; secondary peduncles $12-18,1.5-4.5 \mathrm{~cm}$ long. Flowers $3-7$ per sub-umbels, $1.3-1.5 \mathrm{~cm}$ across; $0.8-1.8 \mathrm{~cm}$ long, slightly thicker towards tip, lax; pedicels ca. $2 \mathrm{~cm}$ long, glabrous, lenticellate. Clayx lobes ca. $1.5 \times$ $1 \mathrm{~mm}$, broadly triangular, margin with glandular cilia, glabrous. Corolla lobes $0.5-0.7 \times 0.3-0.4 \mathrm{~cm}$, ovate, acute, glabrous, decurrent, rosy pink with orange yellow blotches, turns light blue on wilting with 8-9 veins, branched towards tip. Stamens 5, inserted on the throat $0.4-0.5 \mathrm{~cm}$ long; filament $0.1 \mathrm{~cm}$, rosy pink; anther apiculate, basifixed, dehiscence longitudinal, light yellow with orange yellow blotches. Ovary ca. $0.2 \mathrm{~cm}$ diam., globose, glabrous; style $0.5-0.6 \mathrm{~cm}$ long, tapering, entire, tip slightly bending; ovules many on an axile placenta. Berry $0.8-$ $1 \mathrm{~cm}$ diam., globose, glabrous, black on ripening; fruiting pedicel $1.8-2 \mathrm{~cm}$ long. Seed single, $0.6-0.7 \mathrm{~cm}$ diam., sub globose, vertically striate.

\section{Flowering \& Fruiting:- January - July.}

Etymology:- The specific epithet - "nayarii" is named after Dr. M. P. Nayar, the eminent taxonomist, visionary and former Director of Botanical Survey of India, Kolkata for his immense and valuable contribution in the field of Botanical research.

Distribution:- Endemic to Achankovil forests, Kerala, Southern Western Ghats.

Habitat \& Ecology:- Undergrowth in wet evergreen forests in association with Orophea erythrocarpa Bedd., O. uniflora Hook. f. \& Thomson, Mitrephora grandiflora Bedd., Nothopegia aureo-fulva Bedd. ex Hook. f., Saprosma corymbosum (Bedd.) Bedd., Casearia championii Thwaites, Antidesma montana Blume, Coscinium fenestratum (Gaertn) Colebr., Xanthophyllum arnottianum Wight, Pterygota alata (Roxb.) R. Br., Pterospermum rubiginosum B. 
Heyne ex G. Don, Knema attenuata (Wall. ex Hook. f. \& Thomson) Warb., Elaeocarpus tuberculatus Roxb., Harpullia arborea (Blanco) Radlk., Semecarpus auriculata Bedd., Cullenia exarillata A. Robyns etc.

Conservation status:- The proposed species has so far located from only one locality in the Achankovil forests at \pm $250 \mathrm{~m}$ AMSL. About 50 individuals have been noted in 3 populations. As per the IUCN Red List Category Criteria $(2014,2016)$ the area of occupancy of the species is $<5$ sq.km. and hence the taxon is categorized here as " CR (Critically Endangered)".

Notes:- A. paniculata Roxb. has also been recorded from Tamil Nadu (Henry et al., 1987) and Karnataka (Saldanha, 1984). The overall shape of the inflorescence of A. nayarii is pyramidal unlike the oval shape in A. paniculata Roxb. which is having rusty pubescent peduncles and pedicels but the proposed species is different from the above species in that the peduncles and pedicels are glabrous. Another important character noted with A. nayarii is regard to the gland dots. Only those leaves just adjacent to the panicles possess gland dots, that too even on the lower half.

Additional specimens examined:- INDIA, Kerala, Kollam District, Achankovil, \pm 280 m, 09 January 2015, G. Rajkumar, A. Nazarudeen \& M. Alister 83778; ibid 07 February 2015, G. Rajkumar \& A. Nazarudeen, 76554;16 July 2015, G. Rajkumar \& M. Alister 77247 (TBGT). 


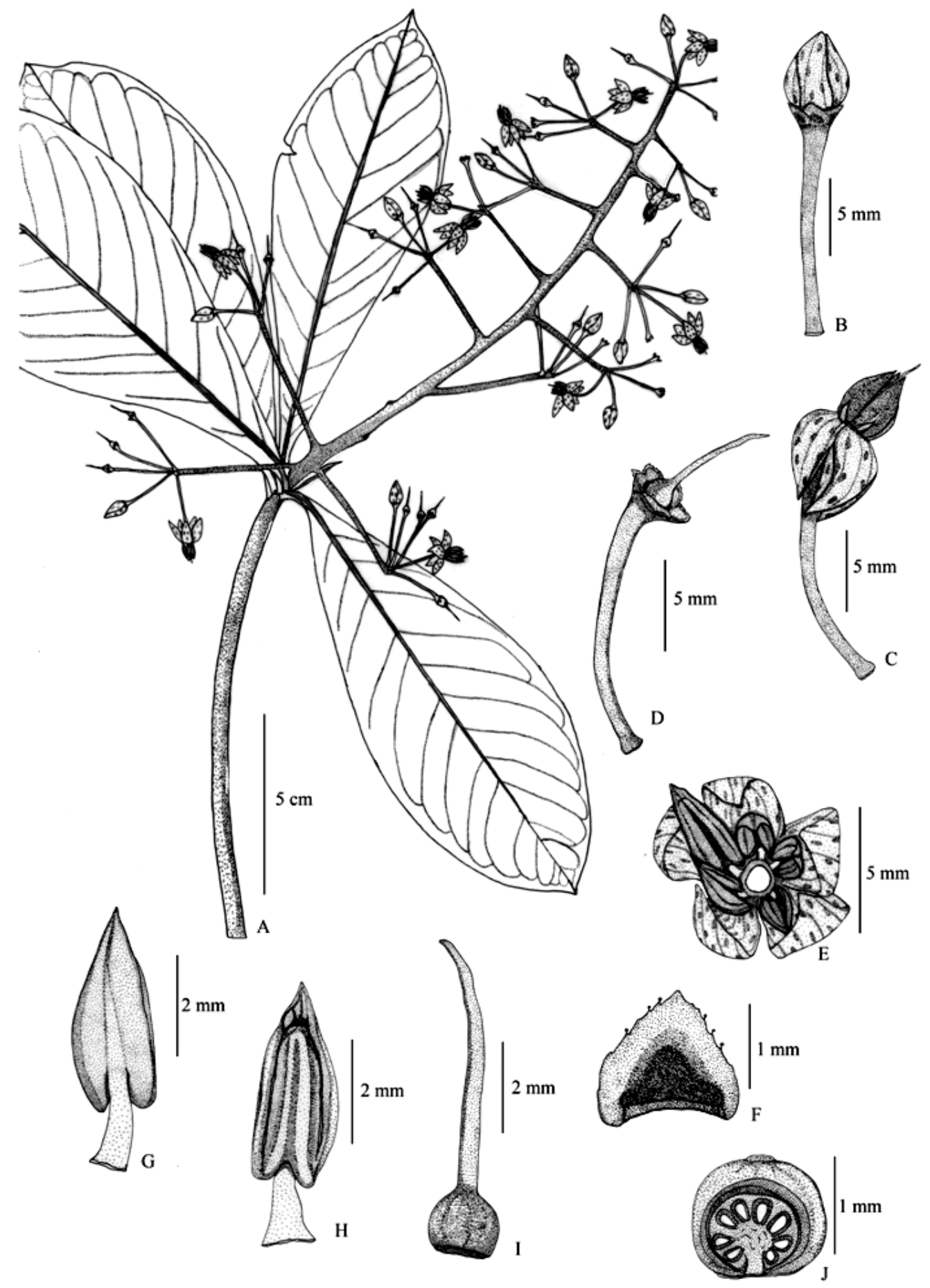

Figure 1. Ardisia nayarii G. Rajkumar, A. Nazarudeen, M. Alister et A. G. Pandurangan sp. nov. A. Habit; B. Flower bud; C. Flower; D. Flower with petals removed; E. Petals with anthers; F. Single calyx lobe; G. Stamen, dorsal side; H. Stamen, ventral side; I. Pistil; J. L. S. of ovary. 


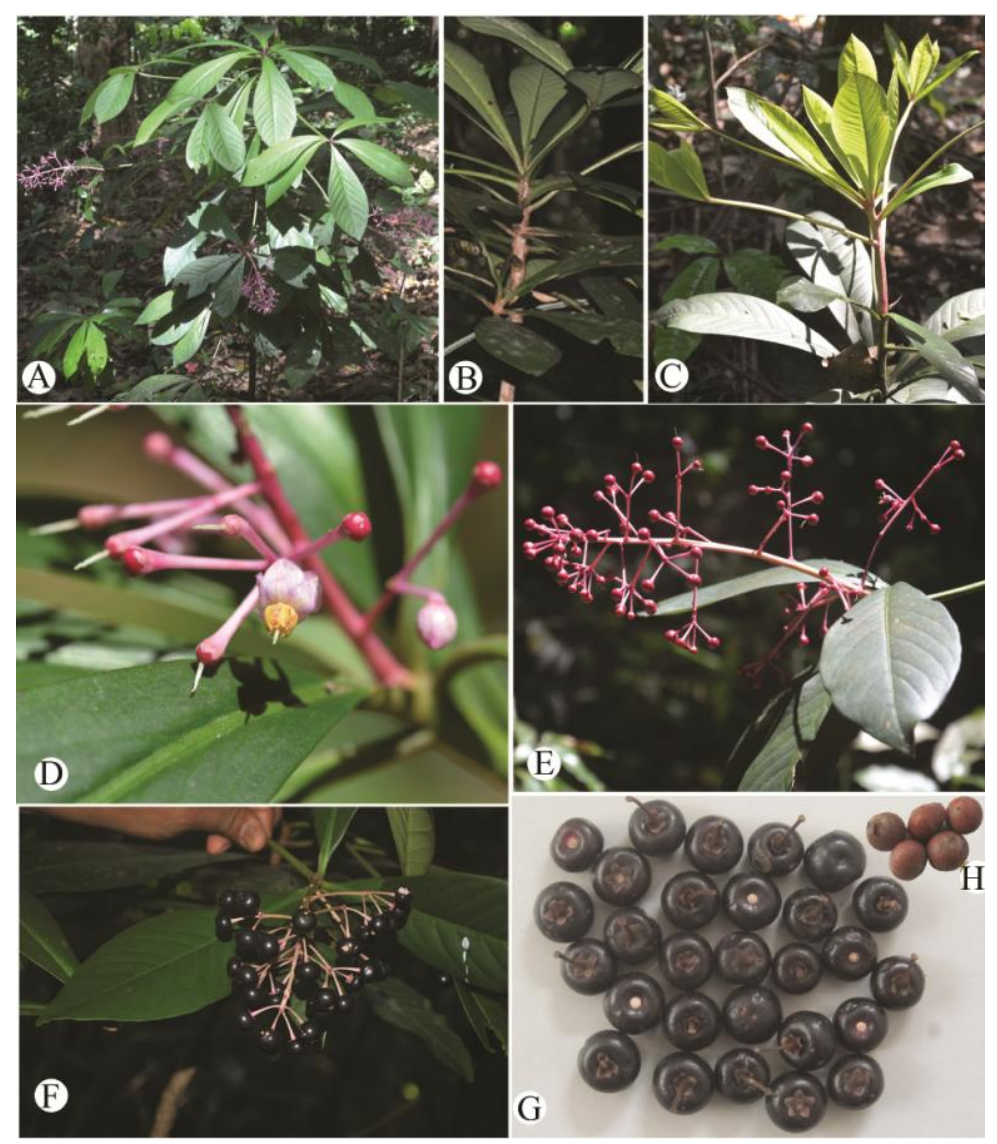

Figure 2. Ardisia nayarii G. Rajkumar, A. Nazarudeen, M. Alister et A. G. Pandurangan sp. nov. A. Habit showing panicles; B. Branch- A closer view; C. Young foliage; D. Single flower; E. Young fruits; F. Ripe fruits; G. Ripe fruits harvested; H. Seeds.

\section{Acknowledgements:-}

The authors express their indebt gratitude towards the Kerala Forest Department for granting permission and support to explore forests. We also thank Head of Office BSI Southern Regional Center, (MH) Coimbatore and Herbarium incharge Calicut University (CALI) for granting permission to consult herbarium. Thanks are also due to the Director, JNTBGRI for providing facilities and encouragement.

\section{References:-}

1. APG III (Angiosperm Phylogeny Group) (2009): An update of the Angiosperm Phylogeny Group classification for the orders and families of flowering plants: APG III. Botanical Journal of the Linnaean Society 161: 105121.

2. Gamble, J.S (1915-1936): Flora of the Presidency of Madras. Adlard \& Son Ltd., London 2.

3. Henry, A.N., Kumari, G. R. and V. Chitra (eds) (1987): Flora of Tamil Nadu, India. Series 1: Analysis. Vol II. Botanical Survey of India, Coimbatore.

4. Hooker, J.D. (1882): The Flora of British India.Vol. 3. L Reeve \& Co., Henrietta Street, Convent Garden, London.

5. IUCN 2014. IUCN Red List of Threatened Species. Version 2014. 3. www. Iucnredlist. org.

6. IUCN Standards and Petition Subcommittee (2016): Guidelines for using the IUCN Red List Categories and Criteria. Version11. Prepared by the Standards and Petitions Subcommittee of the IUCN Species Survival Commission.

7. Available: http://www.iucnredlist.org/documents/RedListGuidelines.pdf (accessed 29 August 2016).

8. Jain, S.K. and R.R. Rao (1977): A Handbook of Field and Herbarium Methods. Today \& Tomorrow, New Delhi. 
9. Mao, Shi-Zhong and Hu Chi-Ming (2013): Ardisia rubricaulis sp. nov. (Primulaceae) from Guangxi, China. Phytotaxa 138: 39-42.

10. Mez, C. (1902): Myrsinaceae In: Engler. A. (Ed.) Das pflanzenreich, Heft 9, IV. Fam. 236. Verlag von Wilhelm Engelmann, Leipzig 1-473.

11. Nayar, T.S., Sibi, M. and A. Rasiya Beegam (eds) (2014): Flowering Plants of the Western Ghats, India. Jawaharlal Nehru Tropical Botanic Garden \& Research Institute, Palode, Thiruvananthapuram, Kerala, India.

12. Nayar, M. P. and G. S. Giri, (1975): Ardisia meghalayensis new species Myrsinaceae from Northeast India. Journal of the Bombay Natural Hiatory Society 72: 825-826.

13. Roxburgh, W. (1824): Flora Indica or Descriptions of Indian Plants. Vol. 2. Duplicat De La Bibiliotheque Du Conservatoire Botanique De GeneveVenduEn., Mission Press, Geneva.

14. Saldanha, C. J. (1984): Flora of Karnataka. Vol.1. Oxford \& IBH Publishing Co., New Delhi. 